\title{
DAMPAK PENGGUNAAN \\ MEDIA PEMBELAJARAN BERBASIS ICT \\ TERHADAP HASIL BELAJAR PAI PESERTA DIDIK \\ PADA SMK NEGERI 1 KOTA PAREPARE
}

\author{
Tanwir \& H. Abd. Rahman F \\ tanwir@stainparepare.ac.id \\ abdrahmanfasih@stainparepare.ac.id \\ Instutut Agama Islam Negeri (IAIN) Parepare
}

\begin{abstract}
The main issue of this article is the successful learning of students through the use of information and communication technology (ICT) based PAI learning media at SMKN Parepare. This article is to know the impact of the use of ICT in PAI learning at SMK Negeri 1 Kota Parepare. The method used in this study is qualitative with the procedure of collecting data through: interviews, observation and documentation. The informants used as sources were all PAI teachers, Principals, KTU, several specified teachers, Computer Operators and students. Data analysis uses data reduction, presentation and verification. Data is verified using an estimation technique. This study shows that the use of information and communication technology (ICT) based learning media in PAI learning at State Vocational High School 1 in Parepare City has run optimally, and supports positivity, both for students, both for teachers, who use the equipment used to deliver messages -message of learning from the sender to the recipient of the message so that it can help students' thoughts, feelings, concerns and interests occur and increase the efficiency of the learning process.
\end{abstract}

Keywords: ICT -based Media, PAI

\begin{abstract}
ABSTRAK
Isu utama dari artikel ini, adalah keberhasilan belajar peserta didik melalui penggunaan media pembelajaran PAI berbasis teknologi informasi dan komunikasi (ICT) pada SMK Neg. 1 Kota Parepare. Penelitian ini bertujuan untuk menggambarkan dampak pemggunaan media ICT dalam pembelajaran PAI di SMK Negeri 1 Kota Parepare,
\end{abstract}


sehingga diketahui segi-segi efektivitas media tersebut dan hasil belajar peserta didik. Metode yang digunakan dalam penelitian ini adalah kualitatif dengan prosedur pengumpulan data melalui: wawancara, observasi dan dokumentasi. Informan yang dijadikan sumber adalah seluruh guru PAI, Kepala Sekolah, KTU, beberapa guru yang ditetapkan, Operator Komputer dan peserta didik. Data dianalisis dengan menggunakan reduksi data, prensentasi dan perifikasi. Data diverifikasi dengan menggunakan teknik trianggulasi. Penelitian ini menunjukkan bahwa penggunaan media pembelajaran berbasis information and communication tehnology (ICT) dalam pembelajaran PAI di SMK Negeri 1 Kota Parepare sudah berjalan dengan maksimal, dan berdampak secara positif, baik terhadap peserta didik, maupun terhadap guru, yang berfungsi sebagai peralatan yang digunakan untuk menyalurkan pesanpesan pembelajaran dari pengirim kepada penerima pesan sehingga dapat merangsang pikiran, perasaan, perhatian dan minat peserta didik sehingga terjadi efektivitas dan efisiensi proses pembelajaran.

Kata kunci: Media Berbasis ICT, PAI

\section{PENDAHULUAN}

\section{Latar Belakang Masalah}

Perkembangan ilmu pengetahuan dan teknologi, telah membawa perubahan yang sangat signifikan terhadap pelbagai dimensi kehidupan manusia, baik dari segi ekonomi, sosial budaya maupun dunia pendidikan. Secara substansial dalam dunia pendidikan, globalisasi juga telah menimbulkan perubahan-perubahan penting, diantaranya terdapat kecenderungan kuat terjadinya penyederhanaan muatan kurikulum. Subjek-subjek yang dipandang tidak terlalu penting dan tidak terlalu relevan dengan kebutuhan global dihilangkan dari kurikulum. Sebaliknya, subjek-subjek yang urgen dan instrumental bagi peserta didik dalam menghadapi realitas-realitas global, semakin mendapat penekanan penting, atau bahkan diprioritaskan.

Globalisasi yang ditandai kemajuan-kemajuan penting dalam teknologi informasi dan komunikasi, mendorong terjadinya pula perubahan-perubahan dalam pembelajaran. Pada presfektif makro, kemajuan teknologi informasi dan komunikasi mempercepat proses demokratisasi dan equity dalam pembelajaran. Guru atau tenaga pengajar saat ini tidak lagi merupakan satu-satunya nara sumber dalam proses pembelajaran. Teknologi komunikasi dan informasi yang kini ada (existing) dan juga yang akan terus berkembang semakin memungkinkan peserta 
didik untuk mengakses sendiri beragam sumber belajar. Karena itu, jika guru atau tenaga pengajar tetap ingin memainkan peran sentral dalam proses pembelajaran, mereka harus melakukan perubahan-perubahan atau setidaknya penyesuaian dalam paradigma, strategi, pendekatan, dan teknologi pembelajaran. Jika tidak, guru atau tenaga pengajar akan kehilangan makna kehadiran dalam proses-proses pembelajaran.

Disamping itu, yang tidak kalah pentingnya untuk diperhatikan bagaimana cara atau strategi dalam proses pembelajaran yang humanis, partisipatoris dan memperhatikan keragaman peserta didik dalam proses pembelajaran. Dalam konteks ini, maka teknikal skill yang dibutuhkan dalam pemahaman yang baik dan menyeluruh terhadap penggunaan media pembelajaran yang berbasis ICT.

Pembelajaran berbasis Information Communication Technology (ICT) merupakan pembelajaran yang berazaskan konsep pembelajaran komputer dan multimedia, yang sudah berkembang pesat di berbagai daerah, sebagai imbas dari perkembangan sains dan teknologi. Hal ini tidak bisa dihindari karena sudah merupakan kebutuhan akan berbagai media interaktif semakin dirasakan, dan kondisi perkembangan teknologi informasi (ICT) semakin berkembang pesat, terutama dalam dunia pendidikan.

Teknologi komunikasi dan informasi pendidikan merupakan salah satu bidang ilmu yang merupakan terapan dari komunikasi dengan memadukan teori psikologi dan pendidikan/pembelajaran. Bidang ilmu ini merupakan hal yang baru berkembang seiring dengan perkembangan teknologi informasi dan komunikasi. Dalam kehidupan sehari-hari tampak bahwa perkembangan teknologi informasi tidak linear lagi, terjadi lompatan yang sulit diprediksi sebelumnya. Hal ini menandakan informasi telah menjadi konsumsi khalayak yang tidak bisa dielakkan. Sebab jika tertinggal dalam penggunaan dan pemanfatan informasi dan teknologi yang membawa sejumlah peristiwa itu, maka pasti ketinggalan. Hal ini berarti ketinggalan oleh perkembangan dunia yang mengglobal.

Salah satu teknologi ICT yang penting dikembangkan saat ini adalah komputer/laptop, karena komputer biasa dipakai sebagai sarana untuk menyajikan informasi dan dapat digunakan di berbagai bidang pendidikan. Sebagai contoh, dengan adanya komputer multimedia yang mampu menampilkan gambar maupun tulisan yang diam dan bergerak serta bersuara. Sudah saatnya komputer dijadikan sebagai salah satu alternatif pilihan media pembelajaran yang efektif dan efisien sebagai bagian penting dari pembelajaran berbasis ICT untuk berbagai mata pelajaran yang diajarkan di sekolah seperti Pendidikan Agama Islam.

Atas dasar itulah, penelitian diperlukan untuk mengetahui bagaimana proses pembelajaran PAI melalui penggunaan ICT, serta bagaimana hasil belajar yang 
dicapai peserta didik dalam mengikuti pembelajaran PAI tersebut. Pertanyaan lain sebagai identifikasi penelitian yang dapat dijadikan alasan adalah, seberapa tingkat kompetensi guru PAI menggunakan perangkat ICT, apakah peserta didik benarbenar mampu dan merasa tertarik untuk mengikuti pembelajaran tersebut karena berdasarkan observasi peneliti, salah satu faktor penyebab bervariasi hasil belajar peserta didik di SMK Negeri 1 Kota Parepare, adalah penyampaian materi pelajaran PAI yang kurang menarik dan tidak adanya media pembelajaran yang diterapkan di dalam proses pembelajaran tersebut, sehingga peserta didik cenderung merasa bosan. Untuk itu, diperlukan solusi yang tepat untuk mengatasi masalah tersebut sehingga diharapkan berdampak pada peserta didik dalam mengikuti pembelajaran PAI.

\section{Tinjauan Pustaka}

Teknologi Pembelajaran

Teknologi adalah penggunaan, pembuatan, dan pengetahuan tentang peralatan, mesin, teknik, hasil kerajinan, sistem atau metode organisasi untuk menyelesaikan persoalan atau melakukan fungsi khusus. Saat ini ketika orang mendengar kata teknologi, pemahaman mereka mengarah pada apa yang disebut dengan komputer, Mp3/MP4 player, dan ruang jejaring, digitalisasi, atau telefon mobile, konferensi melalui video atau audio, dan sebagainya.

Dalam pengertian yang lebih umum, teknologi pembelajaran berarti media yang lahir dari revolusi komunikasi yang dapat digunakan untuk tujuan pembelajaran berdampingan dengan guru, buku paket, dan papan tulis bagianbagian yang membangun teknologi pendidikan mencakup televisi, film, OHP, komputer, dan berbagai komponen yang terdapat dalam hardware (perangkat keras) and software (perangkat lunak).

Tekhnologi informasi yang berkembang pesat pada masa kini menandakan sebagai era globalisasi yang penerapan tekhnologi itu dapat mencakup dimensi dan kebutuhan manusia dalam kehidupannya, tekhnologi informasi kini dipergunakan tidak hanya dalam bentuk memberikan kemudahan infomasi yang dibutuhkan manusia, namun lebih berperan dalam bentuk praktis, penerapan ini pula terlebih menjangkau aktifitas manusia dalam dunia akademik atau dalam pendidikan. Kendati tekhnologi dilahirkan melalui pendidikan, namun dalam pelaksanaan pendidikan yang menuai banyak polemik dan permasalahan sehingga dilahirkan pula yang dinamakan tekhnologi pendidikan. Dengan adanya tekhnologi pendidikan maka proses pendidikan untuk mencapai suatu kualitas pendidikan didukung oleh adanya tekhnologi pendidikan. Dalam kaitan inilah yang urgen dalam pengembangannya sehingga dalam proses pembelajaran masa kini 
khususnya tekhnologi informasi banyak membantu pembelajaran bagi pendidik dan peserta didik.

Dalam kaitan ini, S. Nasution menjelaskan bahwa;

Tekhnologi pendidikan dapat ditafsirkan sebagai media yang lahir dari perkembangan alat komunikasi yang digunakan untuk tujuan pendidikan. Alat-alat itu lazim disebut "hard ware". Ada pula yang memandang tekhnologi pendidikan sebagai suatu pendekatan yang ilmiah kritis, dan sistematis tentang pendidikan. Pendirian itu mengutamakan "software"-nya. Tanpa alat-alat, pendidikan tidak dapat dijalankan. Konsep tekhnologi pendidikan telah membuka lebar dari perkembangan teoritis, penelitian dan implementasinya dilapangan pendidikan. Makna tekhnologi pengajaran dalam pengertian mutakhir meliputi pengelolaan gagasan, prosedur, biaya, mesin dan manusia di dalam proses pengajaran yang melibatkan peralatan fisik yang menyalurkan informasi. ${ }^{1}$

Teknologi adalah keseluruhan sarana untuk menyediakan barang-barang yang diperlukan demi kelangsungan dan kenyamanan hidup manusia. Menurut pengertian di atas, teknologi bisa memiliki banyak arti. Kata sarana bisa diartikan sebagai segala sesuatu yang dapat digunakan sebagai alat atau semacamnya. Teknologi bisa saja sebuah benda maupun bukan benda yang diciptakan untuk mencapai suatu tujuan. Namun pada zaman sekarang, teknologi selalu dikaitkan dengan sebuah alat atau mesin canggih yang memiliki kemampuan untuk mengerjakan hal tertentu. Akan tetapi teknologi tidak selalu sebuah alat atau mesin, melainkan bisa juga sebuah konsep, gagasan, dan juga perangkat lunak yang dapat digunakan manusia untuk mengerjakan sesuatu. Sebagai contoh adalah sebuah telepon yang diciptakan agar manusia bisa berkomunikasi tanpa harus memikirkan jarak dan tempat yang berbeda. Telepon adalah alatnya, dan teknologinya adalah sebuah gagasan, ide, rumusan dan sebagainya yang diperlukan untuk menciptakan sebuah telepon dan membuat telepon itu dapat berfungsi sebagaimana mestinya.

Sebenarnya penggunaan istilah teknologi sudah mengalami banyak perubahan dan memiliki banyak definisi atau pengertian teknologi yang berbeda-beda. Namun kita coba simpulkan arti kata teknologi berdasarkan pengertian di atas. Teknologi bisa diartikan sebagai segala sesuatu apapun itu bentuknya yang diciptakan atau bahkan menciptakan sesuatu yang baru untuk membantu dan memudahkan manusia dalam mengerjakan hal tertentu.

Melalui metode mengajar yang ilmiah diharapkan, proses pembelajaran itu lebih terjamin keberhasilannya. Inilah yang sedang diusahakan oleh tekhnologi pendidikan. Secara ideal diharapkan, bahwa pada suatu saat, mengajar atau

\footnotetext{
${ }^{1}$ S. Nasution, Teknologi Pe ndidikan, (Bandung, Jemmar, 1990), h. 20
} 
mendidik itu menjadi suatu tekhnologi yang dapat dikenal dan dikuasai langkahlangkahnya. Disamping itu perkembangan tekhnologi pendidikan didukung oleh perkembangan yang pesat dalam media komunikasi seperti radio, TV, video tape, computer dan lain-lain yang dapat dimanfaatkan bagi tujuan instruksional. ${ }^{2}$

Tekhnologi pembelajaran secara konseptual mampu memberikan kontribusi dalam Pengembangan organisasi belajar dalam bentuk: Pertama, Pengetahuan tentang pemecahan masalah baik belajar pada perorangan, maupun pada keseluruhan organisasi. Kedua, Penyediaan tenaga profesi (praktis maupun akademis) yang mampu mengintervensi organisasi agar dapat dan mau belajar. Ketiga, Aneka sumber belajar yang sengaja dikembangkan sesuai dengan kebutuhan organisasi. Keempat, System informasi yang diperlukan agar organisasi yang diperoleh akses atas informasi yang terbaru secara tepat. ${ }^{3}$

Dapatlah dipahami bahwa, tekhnologi dapat dipandang sebagai hasil olahan dari ilmu pengetahuan yang diterapkan sebagai hasil yang nyata meliputi kemampuan tekhnik baik dari gabungan piranti software (perangkat lunak) dan hardware (perangkat keras), atau dengan kata lain hasil kreatifitas dan keahlian manusia dalam kehidupannya untuk menunjang keinginan dan kebutuhan manusia tersebut.

Berdasarkan definisi teknologi pendidikan (pembelajaran) seperti telah dijabarkan di atas, dapat dikatakan bahwa: Teknologi pembelajaran pada perkembangan awalnya sama dengan media pembelajaran yang lahir dari revolusi komunikasi. Dalam perkembangan selanjutnya teknologi pembelajaran merupakan suatu disiplin ilmu tersendiri yang bukan hanya terbatas pada media dalam bentuk peralatan fisik semata, melainkan merupakan kajian dan praktek etis dalam mendesain, mengembangkan, menggunakan, mengelola, dan mengevaluasi proses dan sumber teknologi yang sesuai untuk menfasilitasi belajar dan memperbaiki kinerja tenaga pendidik, peserta didik, dan organisasi kependidikan.

1. Hakikat Media Pembelajaran Berbasis ICT

Di era globalisasi saat ini, Informasi Comunikasi Teknology (ICT) merupakan hal yang sangat urgen, bahkan sudah menjadi suatu kebutuhan yang sangat esensi dalam menentukan kualitas dan efektivitas proses pembelajaran. Salah satu usaha menuju kearah tersebut, adalah dengan menggunakan Informasi Communication and Technologi (ICT) dalam proses pembelajaran. ICT dalam konteks bahasa Indonesia disebut dengan Teknologi Informasi dan Komunikasi (TIK) merupakan

\footnotetext{
${ }^{2}$ S. Nasution, Teknologi Pembelajaran, h. 196-197

${ }^{3}$ Yusuf HadiMinarso, Mengetahui Bentuk Teknologi Pendidikan, h. 196 - 197
} 
pembelajaran yang berasaskan konsep pembelajaran computer dan multimedia yang sudah berkembang pesat diberbagai daerah.

Perkembangan ICT yang sangat pesat merupakan sebuah peluang sekaligus tantangan dalam pengembangan media pembelajaran. Perkembangan ilmu pengetahuan dan teknologi yang semakin maju, menuntut adanya pembaharuan dan penggunaan hasil-hasil teknologi dalam proses pembelajaran. Salah satu peran guru dalam rangka menghadapi perkembangan ICT seyogyanya meningkatkan mutu pembelajaran melalui penggunaan media ICT dalam proses pembelajaran. Media merupakan sesuatu yang bersipat menyalurkan pesan dan dapat merangsang pikiran, perasaan dan kemauan audience (Peserta didik) dalam terjadinya proses pembelajaran. Penggunaan media secara kreatif akan memungkinkan audience (peserta didik) untuk belajar lebih baik dan dapat meningkatkan performa peserta didik sesuai dengan tujuan yang ingin dicapai. ${ }^{4}$

Satu hal yang perlu diingat bahwa peranan media tidak akan nampak apabila penggunaannya tidak sejalan dengan isi dan tujuan pembelajaran yang telah dirumuskan. Secanggih apa pun media tersebut, tidak dapat dikatakan menunjang pembelajaran apabila keberadaannya menyimpang dari isi dan tujuan pembelajarann. Media pembelajaran adalah bahan, alat, atau teknik yang digunakan dalam kegiatan pembelajaran dengan maksud agar proses interaksi komunikasi edukasi antara guru dan peserta didik dapat berlangsung secara tepat guna dan berdaya guna. Media pembelajaran yang dipandang sebagai segala bentuk peralatan fisik komunikasi berupa hardware dan software merupakan bagian kecil dari teknologi pembelajaran yang harus diciptakan (didesain dan dikembangkan), digunakan, dan dikelola (dievalusi) untuk kebutuhan pembelajaran dengan maksud untuk mencapai efektivitas dan efisiensi dalam proses pembelajaran. Maka, media pembelajaran sebagai peralatan fisik tidak sama dengan teknologi pembelajaran sebagai suatu disiplin ilmu.

Menurut Heinich dalam Rusman bahwa media merupakan alat saluran komunikasi. Media berasal dari bahasa Latin dan merupakan bentuk jamak dari kata "medium" yang secara harfiah berarti perantara, yaitu perantara sumber pesan (a source) dengan penerima pesan (a receiver). Heinich mencontohkan media ini seperti film, televise, diagram, bahan tercetak, computer, dan instruktur. ${ }^{5}$

Berdasarkan definisi tersebut, media pembelajaran memiliki manfaat yang besar dalam memudahkan peserta didik mempelajari materi pelajaran. Media pembelajaran yang digunakan harus dapat menarik perhatian peserta didik pada

\footnotetext{
${ }^{4}$ Asnawir, M. Basyiruddin Usman, Media Pembelajaran, (Jakarta, Ciputata Perss, 2002), h. 11

${ }^{5}$ Rusman Dedi Kurniawan, Cepi Riyani, Pembelajaran Berbasis Teknologi Informasi dan Komunikasi, Mengembangkan Profesionalisme Guru, (Edisi 1, Rajawali Press, 2013), h. 169.
} 
kegiatan proses pembelajaran dan lebih merangsang kegiatan belajar peserta didik.. Untuk itu dalam pembelajaran perlu adanya media pembelajaran baik melalui pawor point, internet, maupun sejenisnya. Dengan adanya media tersebut setiap peserta didik mampu menggunakan media pembelajaran sesuai dengan kebutuhan pendidikan. Di samping itu penggunaan internet sebagai media pembelajaran sangat mempermudah peserta didik dalam mengakses sebuah informasi pengetahuan, mengirim tugas-tugas sekolah lewat email, dan sebagainnya. Selain peserta didik, guru juga dapat mempermudah dalam menyampaikan pembelajaran. Penggunaan media pembelajaran sangat penting bagi terlaksananya pembelajaran yang baik dan efektif.

Menurut AECT (Association Of Education and Comunication Tecnology) media sebagai segala bentuk dan saluran yang digunakan untuk menyampaikan pesan atau informasi. ${ }^{6}$ Oleh karena itu dalam proses pembelajaran, seorang guru memiliki peranan penting demi tercapainya kegiatan pembelajaran di sekolah. Guru menjadi ujung tombak terciptanya proses pembelajaran yang baik. Meskipun guru mempunyai kecerdasan tanpa didukung dengan media pembelajaran yang baik maka proses pembelajaran itu akan menjenuhkan dan kurang menarik minat peserta didik..

Menurut Rusman, bahwa;

Media yang difungsikan sebagai sumber belajar bila dilihat dari pengertian harfiahnya juga terdapat manusia di dalamnya, benda ataupun segala sesuatu yang memungkinkan bagi peserta didik memeroleh informasi dan pengetahuan yang berguna bagi dirinya dalam pembelajaran dan bagaimana dengan adanya media berbasis TIK tersebut, khususnya menggunakan presentasi powerpoint dimana peserta didik mempunyai keinginan untuk maju dan juga mempunyai kreativitas yang tinggi dan memuaskan dalam perkembangan dirinya di kehidupan yang akan datang. ${ }^{7}$

Kemajuan ilmu pengetahuan dan teknologi, khususnya teknologi informasi, sangat berpengaruh terhadap penyusunan dan implementasi strategi pembelajaran. Melalui kemajuan tersebut para guru dapat menggunakan berbagai media sesuai dengan kebutuhan dan tujuan pembelajaran. Dengan menggunakan media komunikasi bukan saja dapat mempermudah dan mengefektifkan proses pembelajaran akan tetapi juga bisa membuat proses pembelajaran yang lebih menarik. Media yang paling popular saat ini adalah penggunaan computer/laptop, baik penggunaannya dalam bentuk pawor point, internet, dan semacamnya.

\footnotetext{
${ }^{6}$ Azhar Arsyad, Media Pembelajaran, 2000, h. 3

${ }^{7}$ Rusman Dedi Kurniawan, Cepi Riyani, Pembelajaran Berbasis Teknologi Informasi dan Komunikasi, Mengembangkan Profesionalisme Guru, h. 102.
} 
Media pembelajaran merupakan segala bentuk perangsang dan alat yang disediakan guru untuk mendorong siswas belajar secara cepat, tepat, mudah, benar dan tidak terjadinya verbalisme. media pembelajaran merupakan alat bantu pendengaran dan penglihatan (Audio Visual Aid) bagi peserta didik dalam rangka memperoleh pengalaman belajar secara siginfikan. ${ }^{8}$

Penggunaan media ICT dalam pembelajaran merupakan hal yang penting. Setiap komponen yang berada dalam lingkup pendidikan dapat memanfaatkan berbagai aplikasi yang dibutuhkan dengan mudah dan memudahkan mendapatkan berbagai informasi pengetahuan. Sesuai dengan perkembangan teknologi, penggunaan media pembelajaran ICT memiliki dampak yang positif dan negatif. Dampak posistif yaitu bagi peserta didik dapat memperoleh berbagai pengetahuan sesuai dengan kebutuhan pembelajaran, dan bagi guru dapat mempermudah menyediakan media pembelajaran sesuai dengan tujuan pembelajaran dan terciptanya pembelajaran yang menarik. Di samping itu juga ada dampak negative penggunaan media yaitu banyaknya terjadi kejahatan.

Media pembelajaran merupakan suatu alat atau perantara yang berguna untuk memudahkan proses pembelajaran, dalam rangka mengefektifkan komunikasi antara guru dan peserta didik. Hal ini sangat membantu guru dalam mengajar dan memudahkan peserta didik menerima dan memahami pelajaran. Proses ini membutuhkan guru yang professional dan mampu menyelaraskan antara media pembelajaran dan metode pendidikan. Kemajuan teknologi, ilmu pengetahuan serta perubahan sikap masyarakat membawa pengaruh yang besar dalam bidang pendidikan. Hal ini mendorong setiap lembaga pendidikan untuk mengembangkan lembaganya lebih maju dengan memggunakan teknologi modern dan kemajuan ilmu pengetahuan sebagai media pembelajaran.

Menghadapi perkembangan ilmu pengetahuan dan teknologi semakin mendorong upaya-upaya pembaharuan dalam penggunaan hasil-hasil teknologi dalam proses pembelajaran. Para guru dituntut agar mampu menggunakan media pembelajaran dalam kelas yang merupakan keharusan dalam mencapai tujuan pembelajaran yang diharapkan. Disamping mampu menggunakan media pembelajaran, guru juga dituntut untuk dapat mengembangkan keterampilan mendesain media pembelajaran yang akan digunakan. Oleh karena itu guru harus memilki pengetahuan dan pemahaman yang cukup tentang media pembelajaran.

ICT merupakan singkatan dari Information Comukation Tecnology merupakan alat bantu dalam mengajar di kelas dan juga dapat dimanfaatkan untuk pekerjaan

\footnotetext{
${ }^{8}$ NanangHanafiah, Cucu Suhana, Konsep Strategi Pembelajaran, (Cet. III, Bandubg, PT. Redika Aditama, 2012), h. 39
} 
tugas-tuga peserta didik. ${ }^{9}$ Perangkat ICT yang dimaksudkan dalam penelitian ini adalah computer atau laptop dengan menggunakan Software Microsoft Power Point, LCD dan Internet. Menurut Munir bahwa, Istilah Teknologi Informasi dan Komunikasi mempunyai pengertian yang sama dengan istilah Information and Comunikation Tecnology (ICT). ${ }^{10}$ Dengan demikian dalam pembahasan selanjutnya pada penelitian ini, penulis banyak menggunakan istilah TIK untuk mengambil rujukan sebagai pengganti ICT.

Udin Saefuddin Saud, menjelaskan bahwa ICT atau TIK adalah suatu teknologi pemrosesan, pengolahan, penyebaran atau penyajian informasi dengan menggunakan teknologi informasi. ${ }^{11}$ Selanjutnya Munir menjelaskan pula bahwa, yang termasuk produk teknologi informasi dan komunikasi adalah; radio, televise, handphone, laptop, tape, teleconference, internet, computer, jaringan internet dan faximaile. Menghadapi kemajuan teknologi informasi saat ini, maka produkproduk yang dihasilkan teknologi informasi dan komunikasi tersebut merupakan hal yang tidak asing lagi bagi manusia bahkan sudah menjadi kebutuhan untuk membantu dan mempermuda penyelesaian pekerjaan termasuk dalam proses pembelajaran.

Terkait dengan uraian di atas, lebih jauh Deni Darmawan menjelaskan bahwa; Teknologi Informasi dan Komunikasi (TIK) sebagai bagian dari Ilmu Pengetahuan dan Teknologi (IPTEK), secara umum adalah semua teknologi yang berhubngan dengan pengambilan, pengumpulan (akuisisi), pengolahan, penyimpanan, penyebaran, dan penyajian informasi.

Pesatnya perkembangan TIK, khususnya internet, memungkinkan pengembangan layanan informasi yang lebih baik dalam suatu institusi pendidikan. Di lingkungan lembaga pendidikan Sekolah Menengah sudah selayaknya memperkenalkan dan memulai penggunaan teknologi Informasi dan Komunikasi (TIK) sebagai basis pembelajaran yang lebih mutakhir. Hal ini penting mengingat penggunaan TIK merupakan salah satu factor penting yang memungkinkan kecepatan transformasi ilmu pengetahuan kepada para peserta didik, generasi bangsa ini secara luas. Dalam konteks yang lebih sepesifik, dapat dikatan bahwa kebijakan penyelenggaraan pendidikan, baik yang diselenggarakan oleh pemerintah, pemerintah daerah, maupun masyarakat harus mampu memberikan

\footnotetext{
${ }^{9}$ Sujonon, Potensi Pemanfaatan ICT untuk Peningkatan Mutu Pembelajaran SMA di Kota Yogyakarta, (online) tersedia php/ep/artikel/view/337pdf, di akses 10 April 2014

${ }^{10}$ Munir, Kurikulum Berbasis Teknology Informasi dan Komunikasi (Cet.II, Bandung, Alfabeta, 2010), h. 17

${ }^{11}$ Udin Saefuddin Saud, Inovasi Pendidikan, (Bandung, Alfabeta, 2008), h. 183
} 
akses pemahaman dan penguasaan teknologi mutakhir yang luas kepada para peserta didik.

Menurut Sujadi bahwa pengertian pembelajaran berbasis ICT/TIK adalah proses pembelajaran yang diselenggarakan dengan media teknologi informasi dan Komunikasi. Dengan media ini memungkinkan proses belajar mengajar berjalan lebih efektif. Dengan demikian dapat dipahami bahwa, pembelajaran berbasis ICT/TIK tidak hanya sekedar pemanfaatan terknologi informasi dan komunikasi untuk mengantarkan materi pembelajaran, tetapi materi dapat diakses dari local Area Network (LAN) yang dikemas dan dipersiapkan oleh sekolah atau bahkan dapat mengakses materi pembelajaran melalui Interconekting Network (Internet).

Berdasarkan uraian di atas, dapat dipahami bahwa media pembelajaran berbasis ICT/TIK merupakan alat perantara untuk menyampaiakan pesan sehingga dapat mendorong terjadinya proses pembelajaran, dan media tersebut berupa perangkat keras dan perangkat lunak, transparan dan lain-lain. Adapun media pembelajaran berbasis ICT/TIK yang dimaksud dalam penelitian ini ialah media pembelajaran dengan bantuan computer/laptop, melalui media presentasi power point, LCD, video dan internet. Sehubungan dengan hal tersebut Munir menjelaskan bahwa, TIK/ICT dalam pembelajaran berperan sebagai media dalam bentuk Audio Visual Aid, yaitu alat bantu berbentuk audio dan visual (memanfaatkan suara dan gambar) untuk menyampaikan materi pembelajaran.

Cakupan ICT/TIK meliputi; piranti keras dan piranti lunak computer serta fasilitas telekomunikasi, perangkat proyektor/LCD, LAN (Lokal Area network), dan WAN (wide area network), serta mesin computer dan robot. Adapun media pembelajaran yang dimaksud dalam penelitian ini adalah media berbasis ICT/TIK berupa slide power point, yang memuat tulisan, gambar, suar dan video yang ditampilkan melalui LCD dan laptop. Dalam hubungan ini Abdullah dalam Rusman mengklasifikasikan penggunaan/pemanpaatan ICT/TIK dalam pendidikan menjadi tiga jenis yaitu:

Pertama; ICT sebagai media (alat bantu) pendidikan. Artinya hanya sebagai pelengkap untuk memperjelas uraian-uraian yang disampaikan guru. Kedua; ICT sebagai sumber. Pada jenis pemanfaatan ICT ini ICT digunakan sebagai sumber informasi, dalam penggunaannya siswa mencari informasi via ICT berdasarkan bimbingan guru. Ketiga; ICT sebagai system pembelajaran. Pada kategori ini, ICT dirancang sedemikian rupa sebagai suatu system pembelajaran yang terintegrasi. Fungsi media, sumber dan juga system atau prosedur pembelajaran tertentu tercakup.

Berdasarkan uraian di atas, dapat dipahami bahwa teknologi informasi dan komunikasi dapat digunakan sebagai media dalam pembelajaran yang sangat 
menarik, menyenangkan dan dapat memberikan motivasi belajar kepada peserta didik. Di samping itu, fasilitas pembelajaran dapat dimanfaatkan secara maksimal jika dilengkapi dengan fasilitas internet. Internet merupakan perpustakaan maya yang menyimpang banyak ilmu pengetahuan. Dengan demikian hal ini menggambarkan bahwa penggunaan media pembelajaran berbasis ICT yang dimaksud dalam penelitian ini meliputi penggunaan peralatan dan media ICT. Perealatan ICT meliputi computer beserta perangkatnya, LCD, sound system, dan sebagainya yang dapat berupa perangkat keras. Sedangkan ICT sebagai media meliputi program Microsoft office word yang dipakai untuk merancang perangkat pembelajaran excel, power point, internet dan sebagainya berupa perangkat lunak. Dengan demikian tekhnologi dapat dipandang sebagai hasil olahan dari ilmu pengetahuan yang diterapkan sebagai hasil yang nyata meliputi kemampuan tekhnik baik dari gabungan piranti software (perangkat lunak) dan hardware (perangkat keras), atau dengan kata lain hasil kreatifitas dan keahlian manusia dalam kehidupannya untuk menunjang keinginan dan kebutuhan manusia tersebut.

\section{PEMBAHASAN}

\section{Penggunaan Madia ICT dalam Pembelajaran PAI di SMK Negeri 1 Kota Parepare}

Penggunaan media TIK/ICT di SMK Negeri 1 Parepare sekitar tahun 2007, sejak itu pula tampak sebuah perubahan secara bertahap pada diri peserta didik,maupun guru, baik dalam hal perhatian, semangat dan motivsi dalam mengikuti proses pembelajaran, maupun dalam hal pengadaan alat media elektronik, seperti Laptop, yang merupakan bagian dari semangat dan antusias peserta didik terhadap penggunaan media pembelajaran berbasis TIK/ICT tersebut.

Penggunaanmedia ICT dalam pembelajaran PAI di SMK Negeri 1 Parepare pada prinsipnya pembelajaran PAI di SMK Negeri 1 Parepare adalah sama yang dilaksanakan oleh SMK dan SMA lainnya dengan tetap mengacu pada aturan dan perundang-undangan yang ada. Namun setiap guru dalam melaksanakan pembelajaran di kelas ditetapkan untuk menggunakan media ICT termasuk pembelajaran PAI. Hal ini menunjukkan sudah menjadi ketentuan bagi setiap guru untuk menggunakan media teknologi pembelajaran. segala aktivitas yang dilaksanakan di sekolah, baik dalam hal pelaksanaan pembelajaran, dan penjadwalannya, maupun pelaksanaan kegiatan lainnya seperti porseni sekolah dan lainnya selalu berdasarkan hasil rapat bersama dengan seluruh guru, karyawan dan komite sekolah.

Dalam pembagian tugas setiap guru, berdasarkan kompetensi keahliannya masing-masing, dengan menekankan penggunaan media pembelajaran di kelas, 
baik dalam bentuk power point, maupun melalui media audio visual, dan multi media sebagai langkah strategis terhadap upaya pelaksanaan program penggunaan ICT di sekolah. Dari keterangan tersebut menunjukkan bahwa di SMK Negeri 1 Parepare, telah melaksanakan program penggunaan ICT dalam proses pembelajaran secara menyeluruh, tidak hanya di tekankan pada jurusan multi media, tetapi justru seluruh guru diharuskan menggunakan media pembelajaran di kelas termasuk pembelaran PAI.

Program penggunaan media teknologi/ICT dalam pembelajaran di kelas mendapt respon dari seluruh guru yang ada, seperti yang dijelaskan oleh Muh. Jufri, bahwa sebagai tenaga guru PAI sangat merespon terhadap penggunaan ICT dalam proses pembelajaran di kelas, karena menyadari bahwa penggunaan TIK/ICT sungguh memiliki keunggulan dan kemudahan timbal balik, baik yang dirasakan oleh guru maupun yang dirasakan oleh peserta didik itu sendiri. Keunggulannya adalah tersedianya informasi secara luas, cepat dan tepat, adanya kemudahan dalam proses pembelajaran dan dukungan teknologi untuk memudahkan proses pembelajaran.

Berbagai respon positif yang diberikan oleh seluruh guru di SMK Negeri 1 terhadap penggunaan media TIK/ICT, seperti penjelasan dikemukakan oleh Nur Amri pelaksana oprasional ICT bahwa, seluruh guru telah menggunakan media pembelajaran berbasis TIK/ICT, termasuk guru PAI, sebagai suatu tuntutan terhadap pelaksanaan program penggunaan TIK/ICT di SMK Negeri 1 Kota Parepare. Penggunaan media tersebut dilandasi oleh suatu perinsip penggunaan media bahwa proses pembelajaran bisa berjalan efektif dan efisien, pembelajaran bisa lebih optimal, pembelajaran lebih menarik, dan dapat merangsang daya kreativitas berfikir peserta didik. Sehingga seluruh guru berupaya secara maksimal untuk bisa menggunakan media pembelajaran di kelas.

Dalam pandangan lain, Kepala Sekolah lebih jauh memjelaskan bahwa sebagai lembaga pendidikan kejuruan, maka penggunaan media TIK/ICT dalam proses pembelajaran menjadi suatu keharusan bagi seluruh tenaga guru, untuk mengembangkan kemampuan peserta didik untuk memecahkan permasalahan dalam kehidupan nyata (kontekstual), sehingga pendidikan menjadi relevan dan responsif terhadap tuntutan kehidupan nyata sehari-hari. Demikian juga dapat menumbuhkan pemikiran reflektif serta membantu perkembangan dan keterlibatan aktif peserta didik mengikuti proses pembelajaran.

Kemajuan teknologi informasi dan komunikasi (TIK) telah menciptakan tradisi dan budaya baru. Sehingga Perkembangan ilmu pengetahuan dan teknologi semakin mendorong upaya-upaya pembaharuan dalam penggunaan hasil-hasil teknologi 
dalam proses pembelajaran termasuk pembelajaran PAI. Terkait dengan hal tersebut, Nur Amri pelaksana oprasional TIK/ICT menjelaskan kembali bahwa:

Oleh karena itu dalam pembelajaran perlu penggunaan media pembelajaran baik dalam bentuk power point, audio visual maupun dalam bentuk multimedia dan internet. Melalui penggunaan media tersebut setiap peserta didik mampu memanfaatkan internet sesuai dengan kebutuhan pendidikan. Di samping itu penggunaan/pemanfaatan internet sebagai media pembelajaran sangat mempermudah peserta didik dalam mengakses sebuah informasi pengetahuan, mengirim tugas-tugas sekolah lewat e-mail, dan sebagainnya. Selain peserta didik, guru juga dapat mempermudah dalam menyampaikan pembelajaran. Penggunaan media internet sangat penting bagi terlaksananya pembelajaran yang baik.

Penggunaan media dalam pembelajaran PAI di kelas dalam bentuk powerpoint, audiovisual, multimedia dan kadang-kadang melalui teprekorder jika dibutuhkan. Penggunaan media pembelajaran berbasis TIK/ICT tersebut sangat direspon oleh peserta didik, mereka sangat bergairah, dan termotivasi dalam mengikuti pembelajaran, menarik perhatian, meningkatkan minat belajar, mengembangkan iklim belajar, dan menciptakan penemuan ide-ide dan pandangan dalam pembelajaran. Karena penggunaan media berbasis TIK/ICT dapat menfasilitasi belajar dan dapat meningkatkan pemahaman materi pembelajaran

Muh. Jufri menjelaskan bahwa; "Di SMK Negeri 1 Parepare ini, telah tersedia sejunlah pasilitas meskipun belum sepenuhnya sesuai harapan yang digunakan untuk meningkatkan proses pembelajaran guru dan peserta didik yang memang sudah menggunakan media TIK/ICT secara online melalui WEBSAIT yang beroperasi di lingkungan sekolah, bahkan dapat diakses di mana saja. Hanya saja dalam hal-hal yang berkaitan dengan pembelajaran secara internal hanya bisa diakses oleh guru, tenaga kependidikan dan peserta didik SMK Negeri 1 Parepare dengan menggunakan password masing-masing. Selain itu pula ada E-mail dan facebok khusus yang dapat digunakan untuk saling memberikan dan menerima informasi tentang aktivitas dan hal-hal yang dapat diketahui secara bersama-sama. Penggunaan fasilitas inilah yang memotivasi seluruh kompnen sekolah, utamanya guru dan peserta didik berupaya untuk melengkapi dirinya dengan laptop atau media online lainya."

Zainal. Dalam keterangannya menjelaskan bahwa; melalui proses pembelajaran di kelas yang berbasis TIK/ICT yang merupakan program yang dilaksanakan di SMK Negeri 1, saya selaku guru mata pelajaran PAI betul-betul memperhatikan aspek peggunaan TIK/ICT ini, karena penggunaan media tersebut sangat dirasakan manfaatnya memudahkan dalam menyediakan materi ajar serta pertanyaan-pertanyaan yang mendorong peserta didik berfikir dan memecahkan 
suatu masalah dalam pembelajaran PAI, dimana terjadi interaksi yang bermakna di kalangan peserta didik secara bergairah, memudahkan penyediaan program penilaian yang mendorong peserta didik melakukan unjuk mengerjakan tugas yang diberikan. Dan kita, selaku guru tidak boleh kalah dengan peserta didik dalam memanfaatkan TIK/ICT ini, termasuk mengontrol aktivitas mereka.

Penggunaan media pembelajaran mencakup semua peralatan fisik dan materi yang digunakan oleh guru, tutor, atau pendidik lainnya dalam melaksanakan pembelajaran dan menfasilitasi tercapainya tujuan pembelajaran. Media pembelajaran yang dimaksud mencakup media tradisional yang terdiri atas kapur tulis, handaout, diagram, slide, overhead, objek nyata, dan rekaman video, atau film dan media mutakhir seperti komputer, $D V D, C D-R O M$, Internet, dan konferensi video interaktif. Media yang digunakan dalam media pembelajaran itu tidak memiliki makna yang standar. Kadang-kadang media merujuk pada istilahistilah sebagai berikut: Sensory mode: alat indera yang didorong oleh pesan-pesan pembelajaran (mata, telinga, dan sebagainya). Channel of communication: alat indera yang digunakan dalam suatu komunikasi (visual, auditori, alat peraba, kinestetik, alat penciuman, dan sebagainya). Type of Stimulus: peralatan tapi bukan mekanisme komunikasi, yaitu kata-kata lisan (suara asli atau rekaman), penyajian kata (yang ditulis dalam buku atau yang masih tertulis di papan tulis), gambar bergerak (video atau film). Media: peralatan fisik komunikasi (buku, bahan cetak seperti modul, naskah yang diprogramkan, komputer, slide, film, video, dan sebagainya).

Dengan demikian yang dimaksud dengan media pembelajaran adalah peralatan fisik apa saja (bahan cetak, teks, objek nyata, audio, visual, video, Internet, dan berbagai media interaktif yang menggunakan DVD dan CD Rom) yang didesain secara terrencana dan sistematis untuk menyampaikan pesan-pesan pembelajaran dengan maksud menciptakan kondisi belajar yang efektif dan efisien. Dalam wawancara selanjutnya dengan Nur Amri, selaku pelaksana oprasional penggunaan media TIK/ICT di SMK Negeri 1 Parepare, dijelaskan bahwa :

Media pembelajaran yang dipandang sebagai segala bentuk peralatan fisik komunikasi berupa hardware dan software merupakan bagian kecil dari teknologi pembelajaran yang harus diciptakan (didesain dan dikembangkan), digunakan, dan dikelola (dievalusi) untuk kebutuhan pembelajaran dengan maksud untuk mencapai efektivitas dan efisiensi dalam proses pembelajaran. Oleh karena itu, media pembelajaran sebagai peralatan fisik tidak sama dengan teknologi pembelajaran sebagai suatu disiplin ilmu. Sumber belajar dipahami sebagai perangkat, bahan (materi), peralatan, pengaturan, dan orang di mana pembelajar dapat berinteraksi dengannya yang bertujuan untuk menfasilitasi belajar dan memperbaiki kinerja 
Perangkat yang dimaksud di sini adalah perangkat keras dan lunak yang digunakan untuk menciptakan video training, yang kemudian direkam atau dihasilkan sebagai materi atau bahan. Sementara, yang dimaksud dengan bahan adalah aliran jaringan digital, kaset video analog, dan DVD digital untuk meningkatkan kualitas yang digunakan untuk menyimpan video training yang dapat dilihat melalui peralatan. Sedangkan, yang dimaksud dengan peralatan di sini adalah komputer multimedia, VCR analog, DVD-player digital, dan komputer yang dilengkapi dengan DVDROM yang berfungsi untuk meningkatkan kualitas yang lebih sederhana dari pada perangkat yang digunakan untuk mengakses bahan.

Terkait dengan penggunaan media TIK/ICT dalam pembelajaran PAI di SMK Negeri 1 Parepare Hj. Harwiani menjelaskan sebagai guru PAI bahwa; Dalam penggunaan media TIK/ICT dalam pembelajaran PAI di kelas, kami menggunakan dalam bentuk pawor poin, yang telah didesain sebelumnya, berdasarkan RPP yang ada. Disamping itu juga kadang-kadang menggunakan media audio-visual, dan multimedia, yang memperlihatkan langsung materi pelajaran sekaligus memperdengarkan penjelasan pada setiap materi ajar PAI. Misalkan dalam menjelaskan tentang hari qiamat, cara berwudhu yang benar, cara shalat yang sesuai dengan tuntunan ajaran Islam, demikian pula dalam pelajaran baca tulis Alqquran, kami menggunakan beberapa jenis media teknologi, maupun dalam bentuk alat-alat praga yang kami telah siapkan sebagai alat penunjang dan pendukung dalam melaksanakan proses pembelajaran secara baik dan bermutu, sesuai yang di amanahkan dalam undang-undang dan peraturan Pemerintah. Kami juga selalu berupaya secara maksimal dalam menerapkan penggunaan media teknologi dengan baik dan menarik bagi peserta didik, karena mereka sudah mahir dalam penggunaan TIK/ICT.

Gambar di bawah ini merupakan salah satu cara yang di gunakan $\mathrm{Hj}$. Harwiani dalam pembelajaran PAI di kelas, yang di tayangkan melalui media pembelajaran. Cara ini menurutnya sebagai upaya yang dilakukan untuk menunjukkan unjuk kerja maksimal yang diharapkan dapat menarik minat, gairah, dan motivasi peserta didik dalam mengikuti pembelajaran PAI. (Sumber Data; Salinan dari materi ajar Hj. Harwiani. Tahun pembelajaran 2016/2017)

Upaya dan cara yang dilakukan setiap guru PAI seperti itu, merupakan salah satu upaya yang mencerminkan cara professional yang menunjukkan kompetensi pedagogik yang dimiliki, yang tentu saja diharapkan dapat meningkatkan perhatian, dan motivasi belajar peserta didik, sehingga hasil pembelajaran yang di diperoleh akan bernilai baik, sesuai diharapkan. Melalui hasil wawancara peneliti dengan Bapak Muh. Jufri beliau juga menjelaskan Bahwa: 
Sebagai guru PAI pada SMK Negeri 1 Parepare, dalam penggunaan media TIK/ICT, betul-betul kami sungguh-sungguh memanfaatkannya dengan baik dan menggunakan pendekatan strategi pembelajaran yang tepat guna dan tepat sasaran, sehingga langkah awal yang dilakukan adalah mengkaji dan mendalami arah kurukilum yang digunakan (K. 13), lalu kemudian dijabarkan dalam silabus, selanjutnya dibuatlah kerangka acuan pembelajaran dalam bentuk RPP. Landasan inilah kemudian kami buat desain pembelajaran, baik dalam bentuk pawor poin, maupun dalam bentuk audio-visual, dan multimedia, yang selanjutnya di laksanakan dalam proses pembelajaran PAI di kelas. Materi pembelajaran yang dibuat, dikemas dengan baik, melalui berbagai pertimbangan strategi untuk mencapai Standar Kompetensi, Konpetensi Dasar, dan tujuan Institusional, dengan menggunakan indicator-indikator yang ada. Hal ini diupayakan adalah untuk bisa mencapai tiga rana pendidikan, yaitu Kognitif, Apaktif, dan Psikomotorik. Langkah strategis yang diupayakan ini adalah mengharapkan pencapaian hasil pembelajaran yang maksimal dapat diraih bagi peserta didik. Dengan demikian penggunaan media pembelajaran PAI berbasis TIK/ICT, dapat membangkatkan semangat belajar yang tinggi bagi peserta didik, termotivasi, kreatif, inovatif, dan mandiri. Sehingga prospektif kedepan memiliki visioner dalam menghadapi persaingan yang kompetitip.

\section{Hasil Pembelajaran PAI Peserta Didik melalui Penggunaan ICT di SMK Negeri 1 Kota Parepare}

Hasil belajar yang dicapai peserta didik dipengaruhi oleh dua factor utama yakni factor dari lingkungan. Factor yang datang dari diri peseta didik terutama kemampuan yang dimilikinya. Factor kemampuan peserta didik besar sekali pengaruhnya terhadap hasil belajar yang dicapai. Hasil belajar peserta didik di sekolah $70 \%$ dipengaruhi oleh kemampuan peserta didik dan $30 \%$ dipengaruhi oleh lingkungan.

Disamping factor kemampuan yang dimiliki peserta didik juga adalah factor lain, seperti factor motivasi belajar, minat dan perhatian, sikap dan kebiasaan belajar, ketekunan, social, ekonomi, dan factor fisik dan fsikis. Factor tersebut banyak menarik perhatian para ahli pendidikan untuk diteliti, seberapa jauh konstribusi/sumbangan yang diberikan oleh factor tersebut terhadap hasil belajar peserta didik, adanya pengaruh dari dalam diri terhadap hasil belajar peserta didik, ,merupakan hal yang logis dan wajar, sebab hakikat perbuatan belajar adalah perubahan tingkah laku individu yang diniati dan disadarinya. Peserta didik harus merasakan adanya sesuatu kebutuhan untuk belajar dan berprestasi. Ia harus mengarahkan segala upaya untuk mencapainya. 
Berdasarkan hasil evaluasi terhadap 3 guru PAI pada SMK Neger 1 Kota Parepare, dengan menggunakan beberapa pendekatan analisis/tahapan, dengan tetap mengacu pada prosedur dan aturan yang ada yaitu analisis ulangan harian, 1, 2, dan 3, analisis ulangan MID semester dan hasil belajar semester ganjil dan genap (UAS Ganjil dan UAS Genap), menunjukkan bahwa rata-rata peserta didik mendapat nilai dari standar nilai 75 sampai nilai maksimal yaitu nilai 100 . Perolehan nilai tersebut adalah masuk kategori baik (B) dan sangat baik (A). Hasil pembelajaran PAI yang diperoleh peserta didik melalui penggunaan media ICT/TIK tersebut adalah ditunjukkan dalam Rapor masing-masing peseta didik

Dari hasil penelitian tersebut dapat diketahui bahwa hasil penilaian guru PAI SMK Negeri 1 Kota Parepare pada ulangan harian II peserta didik memiliki skor nilai rata-rata 85 dan 90 termasuk kategori sangat baik. Sebagai pendidik professional, guru tidak hanya dituntut melaksanakan tugasnya secara professional, tetapi juga harus memiliki pengetahuan dan kemampuan professional. Dengan demikian sebagai seorang guru telah melaksanakan tugas keguruan dengan kemampuan tinggi sebagai sumber kecerdasan bagi peserta didik.

Dengan memerhatikan perolehan hasil nilai MID Genap pesrta didik SMK Negeri 1 Kota Parepare, terbukti bahwa hasil penilaian Guru PAI tersebut memliki skor antara 90 dan 95, sehingga dapat disimpulkan bahwa perolehan hasil tersebut termasuk dalam kategori sangat baik.

Berdasarkan hasil penelitian terhadap Hasil Pembelajaran PAI Peserta Didik melalui Penggunaan ICT di SMK Negeri 1 Kota Parepare, baik melalui ujian harian, MID semester maupun UAS Genap yang dilaksanakan oleh 3 orang Guru PAI, telah menunjukkan bahwa perolehan nilai peserta didik tersebut adalah termasuk kategori sangat baik, dengan skor nilai rata-rata antara $80,15 \%$ sampai pada nilai 90 atau sekitar $87,29 \%$. Sebuah prestasi yang sangat menggembirakan, sebagai hasil dari penggunaan media dalam proses pembelajaran. Hj. Harwiyani menjelaskan, bahwa hasil perolehan nilai peserta didik dalam pembelajaran PAI berbasis ICT mencapai nilai rata-rata 87,29 \% merupakan bagian dari hasil penggunaan media berbasis ICT di kelas. Karena peserta didik sangat antusias, bergairah, tekun dan termotivasi dalam mengikuti pebelajaran, terutama penyelesaian tugas-tugas yang diberikan sangat cepat . Sehingga dalam mengikuti evaluasi apaun sifatnya paserta didik merasa nyaman, santai dan enjoi dan mendapatkan nilai yang menggembirakan.

Di samping itu Muh. Jufri mengemukakan, bahwa keberhasilan secara matang peseta didik menggunakan media ICT dalam proses pemeblajaran PAI di kelas, menyebabkan perolehan nilai dalam mengikuti setiap tahapan pelaksanaan ujian mendapat nilai yang baik dang sangat menggembirakan. Dengan demikian dapat 
dikatakan bahwa perolehan hasil nilai yang baik bagi peserta didik, merupakan bagian dari dampak positif penggunaan ICT di sekolah, khususnya SMK Negeri 1 Kota Parepare.

Penggunaan media pembelajaran berbasis ICT mengharuskan tenaga pendidik berperan, bukan hanya sekedar memindahkan pengetahuan kepada peserta didik atau sekedar memberi hafalan, melainkan juga harus menjadi fasilitator, perancang pembelajaran, mediator, dan bahkan sebagai manager dalam ruang kelas. Sehingga Peserta didik diharapkan bukan sekedar menghafal, mengerti, dan menguasai isi pembelajaran, melainkan juga mampu menerapkan, menganalisis, mengevaluasi, dan bahkan menciptakan sesuatu yang dibutuhkan dalam dunia nyata.

Setelah melaksanakan pembelajaran, sangat penting melakukan evaluasi untuk mengetahui dampak dari pelaksanaan pembelajaran terhadap prestasi belajar peserta didik. Evaluasi tidak hanya terbatas pada tingkat pengetahuan yang dicapai oleh peerta didik sesuai dengan tujuan pembelajaran, tetapi juga mengukur keseluruhan proses pembelajaran termasuk dampak dari penggunaan media dan tekologi. Jika terdapat kelemahan, atau kekeliruan termasuk tentang bahan ajar, maka perlu dilakukan revisi untuk mendapatkan perbaikan sebagai persiapan untuk digunakan pada hari berikutnya. Evaluasi dan revisi harus selalu dilakukan secara terus-menerus dan berkelanjutan, walaupun sudah pernah dilakukan sebelumnya tetapi bukan berarti semuanya sudah sempurna. Oleh karena itu, dalam melakukan evaluasi dan revisi perlu mempertimbangkan tahapan sebagai berikut:

Pertama menggunakan penilaian otentik dan tradisional untuk menentukan prestasi peserta didik berdasarkan standar dan tujuan. Kedua memeriksa keseluruhan proses pembelajaran dan dampak dari penggunaan media dan teknologi dalam pembelajaran. Ketiga Jika terdapat perbedaan antara tujuan dan hasil belajar, revisi perencanaan pembelajaran untuk lebih menekankan pada fokus yang menjadi perhatian utama. Ketiga tahapan ini dapat dilakukan secara berulangulang jika hasil belajar tidak sesuai dengan tujuan yang telah dirumuskan dalam perencanaan pembelajaran.

\section{Dampak Penggunaan Media ICT dalam Pembelajaran PAI di SMK Negeri 1 Kota Parepare}

Berdasarkan hasil survey dan wawancara terhadap informan di SMK Negei 1 Parepare, baik Kepala Sekolah, tiga Guru PAI, KTU, beberapa Guru mata pelajaran lain, pelaksana oprasional media TIK/ICT dan beberapa peserta didik, menunjukkan bahwa penggunaan media TIK/ICT dalam pembelajaran PAI berdampak secara positif dan bermakna bagi peserta didik dalam mengikuti proses pembelajaran di kelas.Halini merupakan hasil pengamatan dan survey peneliti, 
ketika mengamatinya dikelas, peserta didik mengikutiproses pembelajaran dengan baik, tenang, dan penuh semangat, melalui penggunaan ICT.

Hal yang senada juga di jelaskan oleh Amin Ahmad Pasaid bahwa, penggunaan media pembelajaran PAI yang dilaksanakan di kelas sangat menarik minat bagi peserta didik, sangat termotivasi dalam belajar. Bahkan hampir seluruh peserta didik telah memiliki laptop, sekitar 85 persen. Ini menunjukkan bahwa minat dan motivasi belajar sangat tampak. Bagi peserta didik yang belum memiliki laptop, di arahkan masuk dalam ruang praktek penggunaan media ICT/TIK yang telah disiapkan, disamping mereka belajar juga digunakan media tersebut untuk mempersiapkan materi pelajarannya, yang dibimbing langsung oleh pelaksana oprasional penggunaan TIK/ICT.

Dari segi penggunaan media tersebut sangat besar dampaknya dalam proses pembelajaran terhadap peserta didik. Hal ini ditandai, dari segi penggunaannya, rata-rata peserta didik telah memiliki Laptop, sebagai sarana media untuk digunakan dalam mengikuti pembelajaran di kelas. Bagi merka yang belum memiliki laptop mereka berbondong-bondong ke ruang Laboratorium computer yang telah disiapkan, disamping mereka menyelesaikan tugas-tugas yang ada, juga mengakses data-data yang di perlukan dalam pembuatan tugas dan proses pembelajaran. Dari segi motivasi, semangat, kreativitas dan keaktifannya mereka dalam mengikut pembelajaran di kelas sungguh sangat besar dampaknya. Mereka sangat antusias setiap saat mengikuti pembelajaran. Demikian pula hasil prestasi yang diraihnya juga sangat menggembirakan. Dengan demikian dapat dikatakan bahwa pada perinsifnya penggunaan media ICT/TIK betul-betul berdampak positif terhadap peserta didik dalam proses pembelajaran PAI.

Berbicara tentang dampak penggunaan media ICT/TIK di SMK Negeri 1 Parepare berbagai pandangan yang diberikan oleh para guru dan tenaga Administrasi yang semuanya berorientasi pada dampak yang positif. Dalam wawancara dengan Hj. Andi Fatimah Syarif, beliau menjelaskan bahwa:

Merupakan suatu kebanggaan tersendiri di SMK Negeri 1 Parepare, karena sejak tahun 2007 telah diprogramkan penggunaan media TIK/ICT, bagi seluruh guru dalam proses pembelajaran sampai saat sekrang. Dan hasilnya atau dampanya sangat dirasakan, bukan hanya peserta didik saja, termasuk tenaga pendidik dan kependidikan sangat merasakan dampaknya yang begitu besar. Misalkan dalam mengakses, dan mengimput data yang dibutuhkan untuk kelengkapan adminstrasi sekolah dan semua hal yang terkait dengan itu, seperti data peserta didik, data guru, pegawai, hasil evaluasi dan sebagainya, sangat memudahkan bahkan meringankan dalam menyelesaikan beberapa pekerjaan, demikian pula kaitannya dengan proses pembelajaran, sangat jelas dampak penggunaan madia TIK/ICT. Bagi peserta 
didik, kelihatan mereka merasa tertarik, memiliki semangat belajar yang tinggi, demikian juga sangat termotivasi dalam mengikuti pembelajaran di kelas. Bahkan mereka sudah mampu mendesain suatu materi ajar sebagai penugasan yang diberikan kepada guru mereka masing-masing. Semangat berkreatif, berinovasi dan menggagas sebuah desain yang ditugaskan oleh kelas, mereka sudah terbiasa dan mahir.

Senada apa yang disampaikan oleh Muh. Jufri beliau menjelaskan bahwa: Melalui penggunaan media TIK/ICT di kelas, sangat berdampak secara positif bagi peserta didik dalam banyak hal. Diantaranya; a) menjadi penyemangat, motivasi, dalam mengikuti proses pembelajaran di kelas, b) memiliki insiatif yang tinggi dalam berkreasi, c) memiliki semangat inovasi, baik dalam hal merancang dan mendesain tugas-tugas yang diberikan,, maupun dalam hal mengakses dan mengimput data-data yang dibutuhkan dalam menyelesaikan tugas melalui penggunaan internet. Sehingga dikalangan peserta didik sangat mahir dalam penggunaan media pembelajaran yang berbasis TIK/ICT.

Data yang diperoleh tersebut, menujukkan bahwa pada dasarnya penggunaan media TIK/ICT dalam proses pembelajaran di SMK Negeri 1 parapare, merupakan hal yang tak terbantahkan terhadap betapa besar dampaknya terhadap pembelajaran PAI, yang tentu saja diharapkan melalui penggunaan media tersebut, dapat menjadi perangsang bagi peserta didik dalam menkaji dan memahami nilai-nilai Islam secara benar, kaffah, sekaligus teraplikasikan dalam kehidupan sehariharinya. Sehingga setiap langkah yang dilakukan selalu mencerminkan aplikasi nilai-nilai islam, dan pada akhirnya akan melahirkan peserta didik yang berakter, memiliki akhlak yang mulia, sopan santun dan beretika. Demikian pula atas dasar dan upaya inilah peningkatan mutu pendidikan dapat terwujud.

Selanjutnya data yang diperoleh melalui wawancara dengan Ibu $\mathrm{Hj}$. Harwiani, menegaskan bahwa; adalah suatu kebanggaan bagi kami selaku guru PAI, atas kemampuan selama ini ditunjukkan oleh anak-anak kami tidak hanya di kelas, bahkan diluar kelas, mereka sangat mahir dalam menggunakan media TIK/ICT. Mampu merancang dan mendesain tugas-tugas yang diberikan kepada mereka setiap minggu. Semangat berkarya, semangat belajar, tampak dalam diri setiap anak, masuk di ruang laboratorium computer setiap hari merupakan kerjaan rutin mereka, untuk memanfaatkan media yang disiapkan maupun milikinya mereka sendiri. Ini merupakan suatu bukti nyata bahwa sungguh sangat besar dampak yang ditimbulkan penggunaan media TIK/ICT dalam pembelajaran PAI.

Hasil observasi peneliti dan rumusan penjelasan diatas, memberikan suatu keyakinan yang mendalam dan tidak lagi diragukan, bahwa sudah saatnya bagi setiap lembaga pendidikan tingkat SLTA, baik SMA, Madrasah, terlebih lagi SMK 
sebagai sekolah kejuruan, seyogyanya menggunakan media TIK/ICT dalam pembelajaran di kelas. Karena hal tersebut sangat bermanfaat dan berguna terhadap peningkatan mutu pendidikan, yang dampaknya sangat besar terhadap peningkatan hasil belajar peserta didik, mencerdaskan, membangkitkan semangat berinofatif, dan berkreasi. Sehingga peserta didik dalam menyongsong masa depan yang kompettitf, akan mampu merespon sekaligus menyikapi berbagai tantangan kedepan. Dalam kaitan ini Zainal sebagai salah seorang guru PAI juga menjelaskan bahwa:

Berbagai dampak secara positif yang ditimbulkan terhadap penggunaan media TIK/ICT dalam pembelajaran khususnya PAI yang dapat disaksikan. Antara lain; dalam penggunaan media teknologi berdampak terhadap hal-hal dibutuhkan seorang guru dan peserta didik untuk membantu kegiatan pembelajaran. Memperjelas penyajian pesan agar tidak terlalu bersifat verbalistis (dalam bentuk kata-kata, tertulis atau lisan belaka), Mengatasi perbatasan ruang, waktu dan daya indera, seperti: Objek yang terlalu besar digantikan dengan realitas, gambar, film bingkai, film atau model. Obyek yang kecil dibantu dengan proyektor micro, film bingkai, film atau gambar. Gerak yang terlalu lambat atau terlalu cepat dapat dibantu dengan tame lapse atau high speed photografi. Kejadian atau peristiwa yang terjadi masa lalu bisa ditampilkan lagi lewat rekaman film, video, film bingkai, foto maupun secara verbal. Obyek yang terlalu kompleks (mesin-mesin) dapat disajikan dengan model, diagram, dll. Konsep yang terlalu luas (gunung berapi, gempa bumi, iklim dll) dapat di visualkan dalam bentuk film, film bingkai, gambar, dll. Dengan menggunakan media pembelajaran/pendidikan secara tepat dan bervariasi sifat pasif peserta didik dapat diatasi. Dalam hal ini media pembelajaran berguna dan berdampak untuk: Menimbulkan kegairahan belajar, memungkinkan interaksi yang lebih langsung antara peserta didik dengan lingkungan dan kenyataan, memungkinkan peserta didik belajar sendiri-sendiri sesuai kemampuan dan minat masing-masing. Inilah menurut saya bagian dari dampak penggunaasn TIK/ICT dalam pembelajaran PAI.

Setelah dikemukakan berbagai pandangan yang dijelaskan beberapa informan, baik Kepala Sekolah, wakil Kepala Sekolah, KTU dan guru PAI, maka berikut ini akan diuraikan pandangan dan hal-hal yang dirasakan oleh peserta didik sebagai hasil observasi dan wawancara terkait dengan dampak penggunaan media TIK/ICT dalam pembelajaran PAI di SMK Negeri 1 Parepare. Menurut Muhammad Risaldi, menjelaskan bahwa:

Sebagai peserta didik jurusan Multi media, dampak penggunaan media TIK/ICT, sangat dirasakan hasilnya, baik dalam mengikuti pembelajaran, maupun dalam hal mencari data dan berbagai kebutuhan terhadap penyelesaian tugas-tugas 
yang diberikan oleh guru. Bagi kami yang memili jurusan multi media, sangat senang, karena sesuai jurusan yang kami pilih. Sehingga berbicara tentang dampak penggunaan media TIK/ICT, adalah sangat banyak. Diantaranya sebagai berikut :

1. Mempercepat pemahaman dan penggunaan media elektronik.

2. Mendukung terhadap penguasaan penggunaan elektronik, khususnya computer/laptop.

3. Mempermudah mengakses data-data yang dibutuhkan melalui internet.

4. Menamabah wawasan dan pengetahuan kami terhadap penggunaan teknologi informasi

5. Mempermudah dalam mengikuti pembelajaran

6. Menambah semangat belajar dan berkreatif yang bersifat inovatif.

7. Mempermudah membuka jajaring persahabatan kepada teman-teman seluruh Indonesia.

8. Menjadi bekal yang sangat esensi menghadapi tantangan masa depan yang penuh dengan tantangan kompetitif.

9. Merangsang bangkitnya semangat belajar dan menelesaikan tugas-tugas di sekolah.

10. Menambah pengalaman untuk menjadi operator pada sebuah stansi, dan

11. Mempermudah mencarai lapangan pada bidang teknologi informasi.

Penjelasan dari kalangan peserta didik tersebut menunjukkan bahwa penggunaan TIK/ICT dalam proses pembelajaran membawa dampak yang sangat berpengaruh terhadap peningkatan prestasi peserta didik. yang juga berimbas terhadap peningkatan kualitas pendidikan secara umum. Media pembelajaran merupakan suatu alat atau perantara yang berguna untuk memudahkan proses pembelajaran, dalam rangka mengefektifkan komunikasi antara guru dan peserta didik. Hal ini sangat membantu guru dalam mengajar dan memudahkan peserta didik menerima dan memahami pelajaran. Proses ini membutuhkan guru yang professional dan mampu menyelaraskan antara media pembelajaran dan metode pembelajaran. Kaerunnisa peserta didik jurusan perkantoran menjelaskan bahwa:

Kami sangat merasakan dampak penggunaan TIK/ICT dalam proses pembelajaran di kelas, tidak hanya berdampak terhadap kemudahan-kemudahan yang dirasakan dalam menerima dan memahami pelajaran, tetapi lebih dari itu sangat menunjang terhadap penguasaan keprofesian dalam menghadapi masa depan yang penuh tantangan. Kami bangga bahwa penggunaan media dalam berbagai aplikasi sasngat dirasakan manfaatnya, baik dalam pemanfaatan internet merancang dan mendesain tugas-tugas yang ada dalam pembelajaran yang 
merupakan hal yang penting, maupun dalam rangka mengefektifkan komunikasi antara guru, teman-teman, dan seluruh komponen yang terkait dengan pendidikan. Rapidbe menjabarkan dampak aktivitas pembelajaran terhadap peningkatan kemampuan peserta didik meliputi:

- $10 \%$ dari apa yang dibaca

- $20 \%$ dari apa yang didengar

- $30 \%$ dari apa yang dilihat

- $50 \%$ dari apa yang dilihat dan didengar

- $70 \%$ dari apa yang ditulis dan katakan

- $90 \%$ dari apa yang dikatakan dan dilakukan.

Dari persentase perbedaan pemahaman yang diperoleh melalui berbagai indera seperti disebutkan di atas, maka rancangan media dapat diarahkan untuk mendorong optimalisasi pemanfatan media pembelajaran yang sesuai dengan aktivitas-aktivitas membaca, mendengar, melihat, menulis, mengucapkan dan melaksanakan. Artinya, media audio, visual, vedeo, dan media interaktif seperti yang dijelaskan sebelumnya perlu dikembangkan dalam upaya meningkatkan pengetahuan, pemahaman, dan daya kreativitas peserta didik dalam memperoleh ilmu pengetahuan.

\section{DAFTAR PUSTAKA}

Arsyad, Azhar, Media Pengajaran. Jakarta: PT. Raja Grafindo Persada, 2007.

Aḥmad Farhān, Yusuf, al-Tarbiyah al-Islāmiyah bayn al-Așālah wa al-Ma'āṣirah. Cet. II; t.tp: Dār al-Furqān, 1983.

Al-Qardhawi, Yusuf, Tarbiyah al-Islami fi al-Dar Hasan al-Banna diterjemahkan oleh Bustani A. Gani dan Zainal Abidin Ahmad dengan judul Pendidikan Islam dan Madrasah di Zaman Hasan al-Banna. Jakarta: Bulan Bintang, 1980.

Arikunto, Suharsini,.Prosedur Penelitian; Suatu Pendekatan Praktek. Cet. IX; Jakarta: Renika Cipta, 1993.

Abdul, Majid. Perencanaan Pembelajaran, Mengembangkan Standar Kompetensi Guru. Bandung: PT Remaja Rosdakarya, 2012.

Amir, Feisal Jusuf, Reorientasi Pendidikan Islam. Jakarta: Gema Insani Press, 1995

Anonim, Mengenal Peralatan Teknologi Informasi Komunikasi. Artikel diambil dari http://indonesiaindonesia.com. Diaskses Kamis jam 23:15 tanggal 17 Desmber 2016 
Arief, Armai. Sejarah Pertumbuhan dan Perkembangan Lembaga Pendidikan Islam Klasik. Bandung :Angkasa Bandung, 2004.

Arifin, Zainal, Evaluasi Pembelajaran: Prinsip Teknik Prosedur. Bandung :PT Remaja Rosdakarya, 2013.

Arikunto, Suharsimi. Prosedur Penelitian: Suatu Pendekatan Praktik. Jakarta: Rineka Cipta, 1997.

Azra, Azyumardi. Pendidikan Islam: Tradisi Dan Modernisasi Di Tengah Tantangan Milenium III. Jakarta: Kencana Prenada Media Group, 2012.

Basri, Hasan. Kapita Selekta Pendidikan. Bandung: Pustaka Setia, 2012

Bambang. Warsita, Teknologi Pembelajaran, Landasan Dan Aplikasinya. Jakarta: Rineka Cipta, 2008.

B. Uno, Hamzah, Profesi Kependidikan; Problema, Solusi dan Reformasi Pendidikan di Indonesia (Jakarta: Bumi Aksara, 2007),

Daradjat, Zakiah. Ilmu Jiwa Agama. PT Bulan Bintang: 2010.

Darmawan, Deni. Inovasi Pendidikan: Pendekatan Praktik Teknologi Multimedia dan Pembelajaran Online. Bandung: PT Remaja Rosdakarya, 2012.

Deni Darmawan, Teknologi Pembelajaran, Cet. I, Bandung, PT. Remaja Rosdakarya, 2011.

Dudung, et.al. Ilmu dan Aplikasi Pendidikan. Tt: PT Imperial Bhakti Utama, 2007.

Firmanto Taufik, Islam dan Tekhnologi, dalam Website:http://humaniora .kompasiana.com/agama /2010/11/15/3/319311/islam-dan-teknologi.html, diakses, 17 Januari 2017.

G, Dryden dan J, Vos. Revolusi Cara Belajar (The Learning Revolution): Belajar akan lebih efektif kalau Anda dalam keadaan "fun”. Bandung: Kaifa, 2002.

Hadi, Sutrisno, Metodologi Research. Cet. XX; Yogyakarta: Audi Ofsser, 1987.

H.M.Alisuf Sabri, Ilmu Pendidikan. Jakarta: Pedoman Ilmu Jaya, 2009.

Mappanganro, Implementasi Pendidikan Islam di Sekolah. Ujung Pandang,: Yayasan Ahkam, 2000.

Republik Indonesia, Undang-Undang Sistem Pendidikan Nasional.

Munir, M.I.T, Kurikulum Berbasis Teknologi Informasi dan Komunikasi, Cet. II, Bandung, Alfabeta, 2010,

Saefuddin Udin, dan Nursanti Riandini, Mengenal Teknologi Informasi dan Komunikasi Jakarta, Shakti Adiluhung dan Bee Media Indonesia, 2008,

Surya, Mohamad. Bunga Rampai Guru dan Pendidikan. Jakarta: Balai Pustaka, 2004.

Sutrisno. Pengantar Pembelajaran inovatif, berbasis teknologi informasi dan komunikasi. Jakarta: Gaung Persada, 2011. 
Syafaruddin, Pendidikan Publishing, 2012. Dan Pemberdayaan Masyarakat. Tt: Perdana, UNESCO. Teknologi Komunikasi dan Informasi dalam pendidikan: Kurikulum untuk Sekolah dan Program Pengembangan Guru. Jakarta: Gaung Persada Press, 2009.

Sudjana, Nana, dan Ahmad Rivai, Tekhnologi Pengajaran, Bandung: Sinar Baru, 1992.

Syaiful Sagala, Konsep dan Makna pembelajaran, Untuk Membantu Memecahkan Problematika Belajar dan Mengajar, Cet. V, Bandung, Alfabeta, 2007.

Surjono dan Abdul, Potensi Pemanfaatan ICT untuk Peningkatan Mutu Pembelajaran SMA di KotaYogyakarta. (online) php/cp/artikel/view/337pdf, diakses 10 April 2014

Sindung, Tjahyadi Ilmu, Teknologi dan Kebudayaan”, dalam Tim Dosen Filsafat Ilmu Fakultas Filsafat UGM, Filsafat Ilmu, cet. III. Yogyakarta: Liberty Yogyakarta, 2003.

Soedijarto, Pendidikan sebagai Sarana Reformasi Mental dalam Upaya Pembangunan Bangsa. Jakarta: Balai Pustaka, 2005.

Surjono dan Abdul, 2010.Potensi Pemanfaatan ICT Untuk Peningkatan Mutu Pembelajaran SMA di Kota Yogyakarta. [online].tersedia: php/cp/article/view/337/pdf, diakses 16 Desember 2013.

Warsita, Bambang. Teknologi Pembelajaran, Landasan Dan Aplikasinya. Jakarta: Rineka Cipta, 2008. 